\title{
The diagnosis of Epstein-Barr virus-associated polymorphic B cell lymphoma in immuno- compromised patients: Review of methods
}

Pierre Beauparlant, BSc, Caroline Alfierl, PhD, Jean-Harry Joncas, MD, PhD

\begin{abstract}
P Beauparlant, C Alfieri, J-H Joncas. The diagnosis of Epstein-Barr virus-associated polymorphic B cell lymphoma in immunocompromised patients: Review of methods. Can J Infect Dis 1991;2(3):109-115. Polymorphic B cell lymphoma and diffuse B cell lymphoproliferation associated with Epstein-Barr virus infection is increasingly reported in immunodeficient patients. Accurate diagnosis of these pathologies is essential because the appropriate treatment regimens for the patients in question differ from those for patients with other lymphoproliferative diseases. Two complementary techniques are currently used in the diagnosis and characterization of Epstein-Barr virus-associated B cell lymphomas and diffuse B cell lymphoproliferation. Immunofluorescence allows specific detection of Epstein-Barr nuclear antigens in lymphomatous tissue. Molecular hybridization with the Bam H1-W and/or Bam H1-NJ probes confirms the presence of the Epstein-Barr virus genome in tumour cells. The Bam H1-NJ probe is also useful in determining the clonality of the tumour and the replication mode, episomal or linear, of the viral genome. The polymerase chain reaction method allows detection of the Epstein-Barr virus genome within $24 \mathrm{~h}$ in these tumours and is more sensitive.
\end{abstract}

Key Words: B cell lymphoma, Epstein-Barr virus, Immunofluorescence, Molecular hybridization, Polymerase chain reaction

\section{Diagnostic du virus d'Epstein-Barr associé au lymphome cellulaire B polymorphe chez les patients immunodéprimés: Revue des méthodes}

RESUME: On rapporte des cas de plus en plus nombreux de lymphomes cellulaires B indifférenciés et de lympho-prolifération diffuse des lymphocytes B associés au virus d'EpsteinBarr chez les patients immunodéprimés. Il est essentiel de poser un diagnostic exact, vu que le régime thérapeutique requis n'est pas le même que pour les autres maladies lymphoprolifératives. Deux techniques complémentaires sont présentement utilisées pour le diagnostic et la caractérisation des lymphomes cellulaires B et de la lympho-prolifération diffuse des lymphocytes B, qui sont associés au virus d'Epstein-Barr. L'immunofluorescence

Hôpital Sainte-Justine, Montréal, Québec

Correspondence and reprints: Dr J-H Joncas, 3175, Côte Sainte-Catherine, Montréal, Québec H3T 1C5. Telephone (514) 345-4728

Received for publication September 25, 1990. Accepted December 15, 1990 
permet de déceler les antigènes nucléaires codés par le virus d'Epstein-Barr dans les tissus lymphomateux, tandis que l'hybridation moléculaire utilisant les sondes Bam-H1-W ou Bam H1-NJ confirme la présence du génome du virus d'Epstein-Barr dans les cellules tumorales. La sonde Bam H1-NJ permet également de déterminer la clonalité de la tumeur et le mode de réplication, épisomique ou linéaire, du génome viral. L’amplification de l'ADN viral par la réaction en chaîne à la polymérase permet la détection du génome du virus Epstein-Barr dans ces tumeurs en 24 h et cette méthode est plus sensible.

E PSTEIN-BARR VIRUS, THE CAUSATIVE AGENT OF infectious mononucleosis (1), is a DNA tumour virus associated with Burkitt's lymphoma and nasopharyngeal carcinoma (2). More recently, polymorphic B cell lymphomas and diffuse B cell lymphoproliferations associated with EpsteinBarr virus infection have been reported in patients with congenital (3) and acquired (4-9) immunodeficiencies. These pathological conditions have been reported in transplant patients (4-7), in patients receiving chemotherapy for leukemia (8) and, more frequently, in patients suffering from the acquired immune deficiency syndrome (AIDS) (9). These tumours may be monoclonal or polyclonal, and monoclonal tumours may be associated with chromosomal abnormalities (10). The term 'polymorphic' refers to the histological appearance of these tumours, which may be described as consisting of a mixture of undifferentiated B cell lymphoblasts, immunoblasts and fully differentiated plasma cells (11). Because this virus has the property of immortalizing $B$ cells in vitro, it is thought that the same phenomenon might occur in vivo, leading to B cell lymphomatous proliferations in the absence of adequate immune function. An accurate diagnosis of these tumours is essential because the treatment regimens appropriate for these patients differ from those for patients with other lymphoproliferative diseases. It was reported that two leukemic patients who developed polymorphic B cell lymphomas recovered when immunosuppressive drugs were discontinued, and their leukemia has not recurred to date, after periods of four and six years, respectively (12).

In order to facilitate the diagnosis of EpsteinBarr virus-associated lymphomatous proliferations, the authors report two case studies in which the lymphomas were Epstein-Barr virus positive and monoclonal as assessed by immunofluorescence and molecular hybridization.

\section{MATERIALS AND METHODS Immunofluorescence for detection of viral anti- gens in tissue: Detection of the Epstein-Barr nuclear antigen on imprints and frozen sections of biopsy specimens was performed by anticomple- ment immunofluorescence with positive and nega-}

tive control antisera (13). These reference sera contained no antinuclear antibodies as determined by anticomplement immunofluorescence on the Epstein-Barr virus negative Molt-4 cell line. Determination of tumour clonality by molecular hybridization: Molecular hybridization with a specific Epstein-Barr virus probe (Bam H1-NJ) was used to assess whether the tumour was polyclonal or monoclonal (14). Briefly, the 7 kilobasepair cloned Epstein-Barr virus restriction fragment, Bam H1-NJ, which was constructed by fusion of the outermost $3^{\prime}$ and 5' Bam $\mathrm{Hl}$ fragments of the linear genome while deleting the terminal repeat segments, was labelled with phosphorus-32 by the random priming method (15) with modifications (16). Ten micrograms of tumour DNA was digested with Bam H1, electrophoresed and blotted onto nitrocellulose by the method of Southern (17). After drying for $2 \mathrm{~h}$ in an $80^{\circ} \mathrm{C}$ oven, blots were prehybridized for $3 \mathrm{~h}$ at $42^{\circ} \mathrm{C}$ in 50\% formamide, 6x SSC, $0.2 \%$ polyvinylpyrrolidone, $0.2 \%$ ficoll, $50 \mathrm{mM}$ sodium phosphate (pH 7.0) and $100 \mu \mathrm{g} / \mathrm{mL}$ of sheared, freshly denatured salmon sperm DNA. The radioactive probe (Epstein-Barr virus Bam H1-NJ) was then added to the prehybridization solution, and the blots were incubated in a $42^{\circ} \mathrm{C}$ waterbath overnight. After a series of washes ( 10 mins in $2 \times \mathrm{SSC}$ at $20^{\circ} \mathrm{C}$; 60 mins in $0.1 \times$ SSC plus $0.1 \%$ sodium dodecylsulphate at $60^{\circ} \mathrm{C} ; 3$ mins in $0.1 \times \mathrm{SSC}$ at $20^{\circ} \mathrm{C}$ ), blots were dried in a $60^{\circ} \mathrm{C}$ oven for 30 mins. Autoradiography was performed with Kodak XAR film placed between two Cronex screens.

\section{RESULTS}

The following case studies, used here to illustrate the authors' diagnostic approach, have been discussed in detail elsewhere (12), and will only be briefly described below.

Case 1: A girl suffering from congenital combined immune deficiency associated with adenosine deaminase deficiency died at the age of three years from a monoclonal (IgM and gamma-light chain positive) primary $\mathrm{B}$ cell lymphoma of the brain (Figure 1).

Case 2: A 4-year-old boy, on maintenance chemotherapy for acute lymphoblastic leukemia in remission, subsequently developed primary 


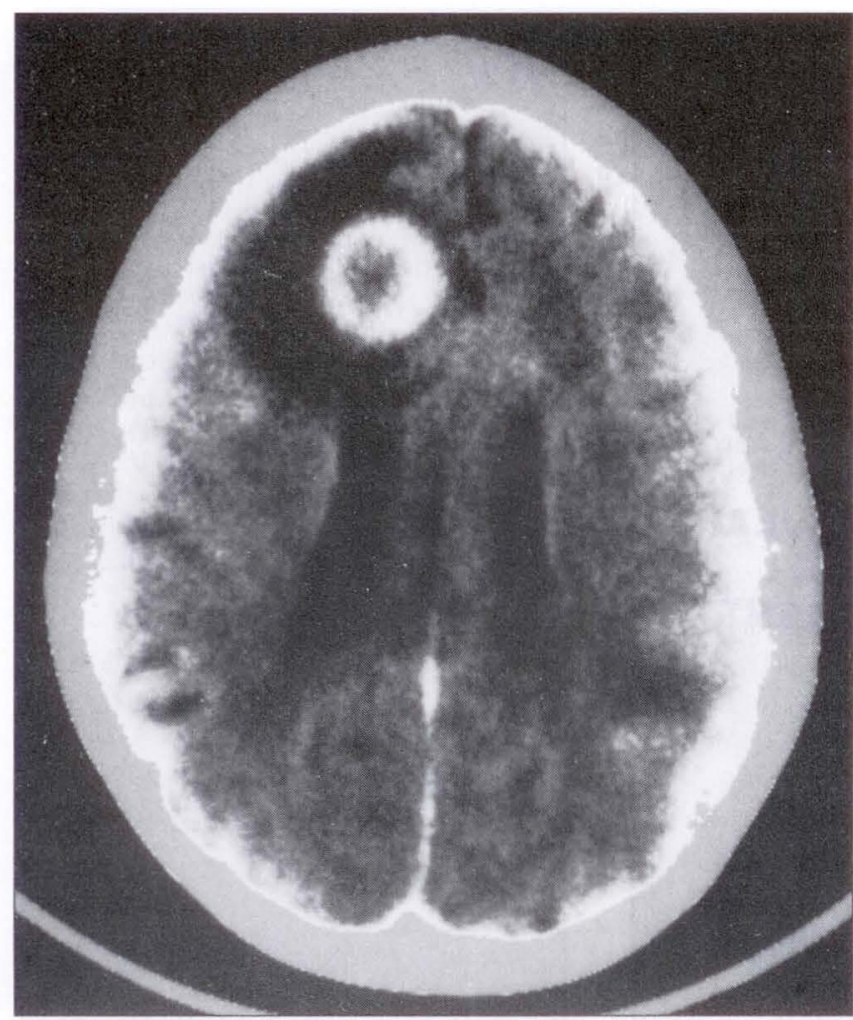

Figure 1) Computed tomography scan of a primary B cell lymphoma of the brain (case 1)
Epstein-Barr virus infection and intestinal tumours. These tumours were polymorphic in appearance: one was positive for IgA-kappa and another for IgM-gamma, suggesting multiclonality.

Immunofluorescence studies using a human Epstein-Barr nuclear antigen positive antiserum revealed Epstein-Barr nuclear antigens in the fresh tumour cells (imprints and frozen sections) from both cases (Figure 2). No fluorescence was observed with the negative control serum.

Molecular hybridization using the Bam H1-NJ probe was performed on DNA extracted from control laboratory cell lines P3HR-1, B95-8, Raji and Molt-4, as well as from tumour biopsies obtained from cases 1 and 2 (Figure 3). Molt- 4 is a $\mathrm{T}$ cell leukemia line which is negative for Epstein-Barr virus. The Raji cell line, which is nonproductive for virus replication, contains approximately 50 copies of episomal Epstein-Barr virus DNA per cell but no linear Epstein-Barr virus DNA (18). The virus-producing P3HR-1 and B95-8 cell lines contain linear Epstein-Barr virus genomes in addition to episomal copies (19-21). Hybridization results reveal the presence of one high molecular weight band for both Raji and the tumour biopsies (Figure 3). Thus, one may deduce that the Bam H1-NJ probe identified the large fused terminal regions of
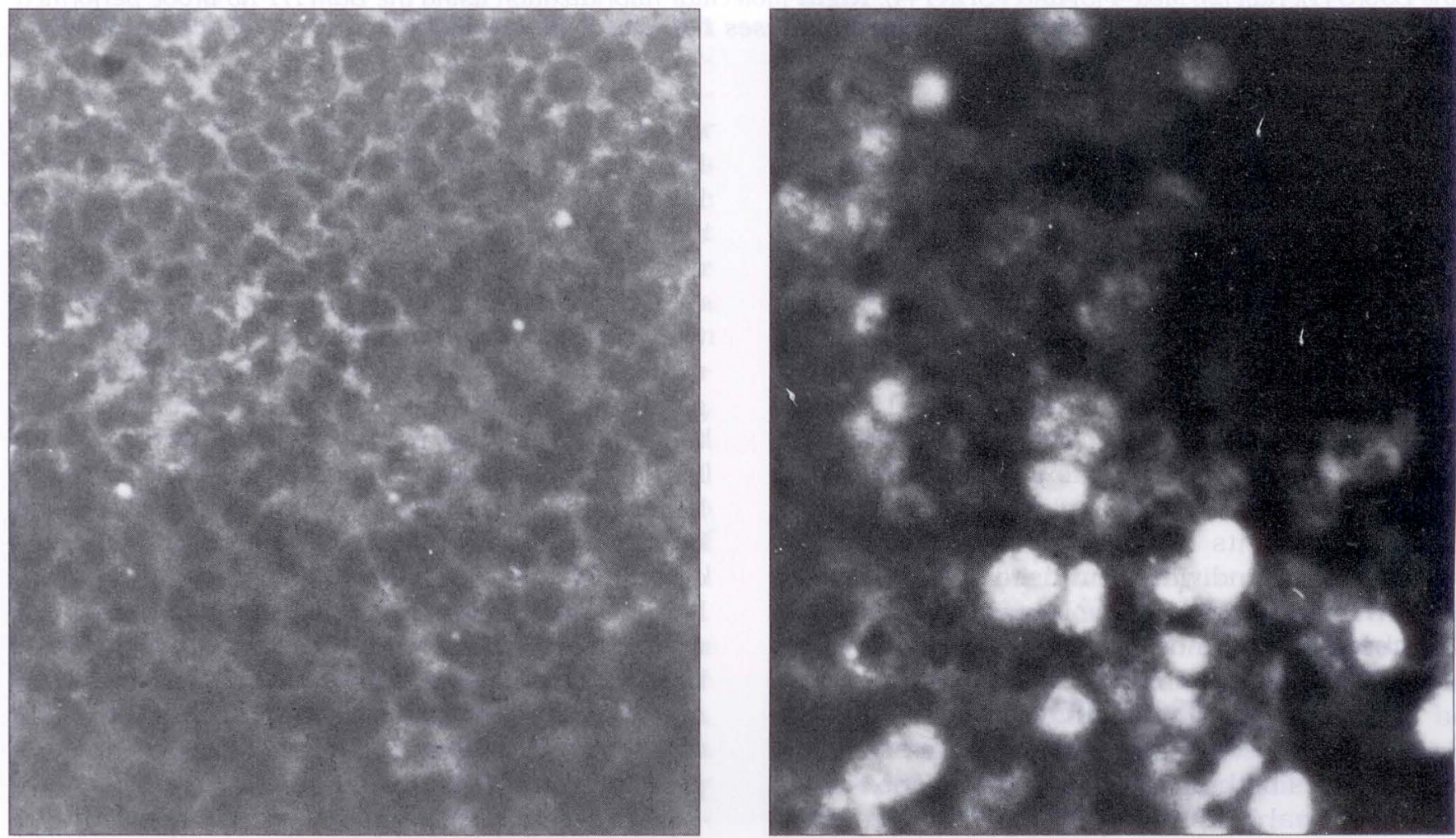

Figure 2) Anticomplement immunofluorescence with positive (left) and negative (right) control antisera on fresh tumour cells from case 1 


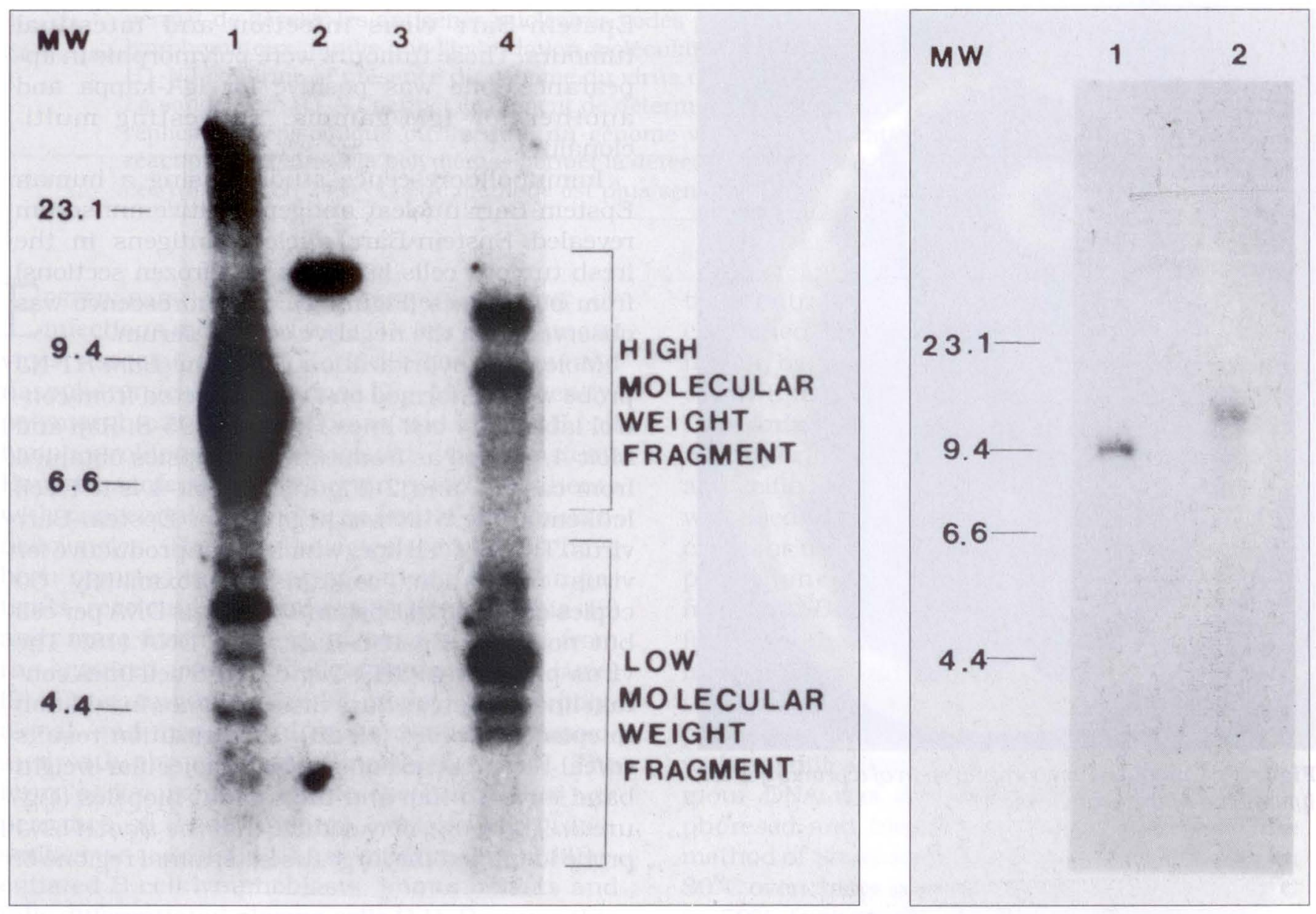

Figure 3) Left Molecular hybridization using Bam H1-NJ probe performed on DNA extracted from the laboratory cell line B95-8 (1), Raji (2), Molt-4 (3) and P3HR1 (4). Right Molecular hybridization using the Bam H1-NJ probe performed on DNA extracted from tumour biopsies obtained from cases 1 (1) and 2 (2). MW Molecular weight in kilobasepairs

the Epstein-Barr virus episome consisting of the Bam H1-N fragment plus the Bam H1-J fragment linked by the presence of a clonally defined number of terminal repeat segments (each consisting of 500 basepairs) (14). These findings confirmed the monoclonality of the tumours.

Molecular hybridization on B95-8 and P3HR-1 viral DNA demonstrated multiple DNA fragments of molecular weights ranging from 4.4 to 9.4 kilobasepairs (Figure 3). The high molecular weight fragment corresponds to the fused region of the Epstein-Barr virus episome, as described above. Fragments of low molecular weight correspond to the individual unfused Bam $\mathrm{H} 1-\mathrm{N}$ and Bam H1-J segments of the linear genome, each attached to one or more terminal repeat units (14).

\section{DISCUSSION}

Epstein-Barr virus infects and transforms B lymphocytes both in vitro and in vivo. The resulting polyclonal lymphoblastoid cell lines generally carry multiple episomal (circular) copies of the genome and express only latent Epstein-Barr virus antigens. In the occasional cell, EpsteinBarr virus is spontaneously reactivated leading to lytic antigen expression. In cases in which lytic antigen expression culminates in the production of virions, the presence of linear genomes can be demonstrated (22). In vitro studies have shown that acyclovir is effective only in reducing the number of linear replicative Epstein-Barr virus genomes $(19,23)$. Acyclovir, when used therapeutically in the treatment of polymorphic B cell lymphoma associated with Epstein-Barr virus, is believed to prevent viral replication and thus to block the spread of infection to other B lymphocytes (24), thereby limiting extension of the lymphoproliferative process. Acyclovir has been reported to influence the outcome of polyclonal, but not monoclonal, tumours (11). However, the major factor influencing the outcome of this tumour appears to be the relief of an immunosuppressive state (25).

A monoclonal tumour is one that originates from a single infected cell, whereas a polyclonal tumour evolves from multiple infected cells. Mul- 


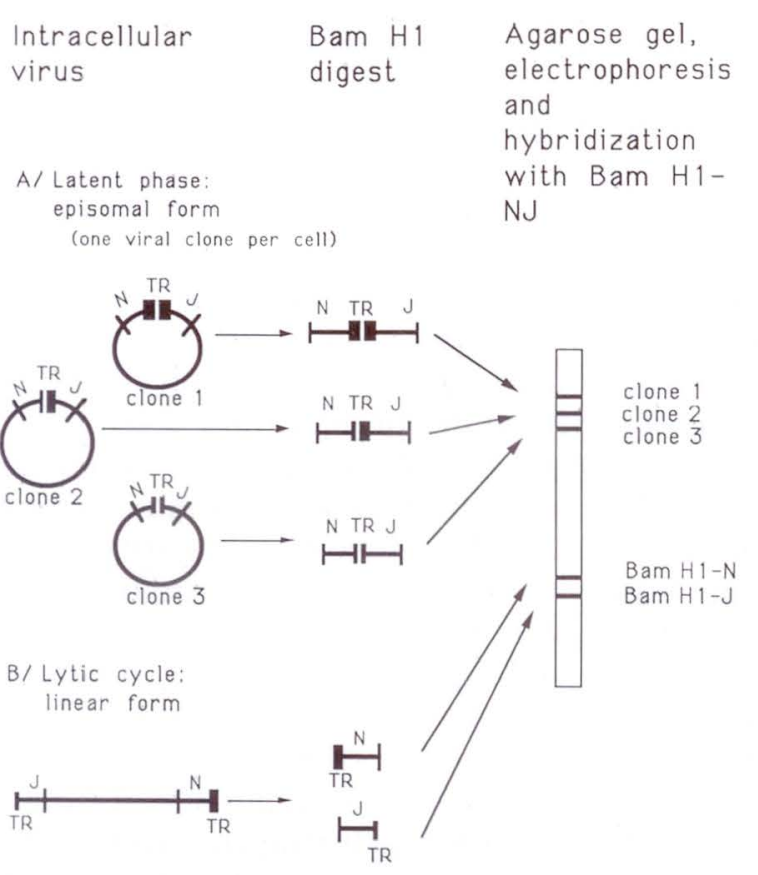

Figure 4) Schematic representation of hybridization results with Bam H1-NJ probe to determine tumour clonality and the form of Epstein-Barr virus DNA (episomal or linear) contained in cell lines or lymphoma tissue. TR Terminal repeat segment

ticlonal tumours are clonally distinct tumours, all of which originate from a single infected cell. Epstein-Barr virus replication is associated with the linearization of the viral genome at the terminal repeat segment. Virions differ in the number of terminal repeat segments contained in their genomes (14). Thus, if each clone of cells results from the proliferation of one cell infected by one virus particle, then the number of terminal repeat segments in all of the episomes in the clone will be identical, yielding only one upper band in a Southern blot of the DNA when probed with Bam H1-NJ. This upper band is composed of the terminal Bam H1-N and Bam H1-J fragments joined, in a given episome, by means of a determined number of terminal repeat segments. A polyclonal population will, on the other hand, give rise to multiple upper bands, because the number of terminal repeat elements varies among the clonal populations comprising the polyclonal tumour. This occurs as a result of the mode of replication of the virus (26). Based on this information, one may conclude that the Raji cell line is monoclonal, as well as the tumours in cases 1 and 2 in which no virus replication can be demonstrated by Southern blot analysis. Because of virus replication in the B95-8 and P3HR-1 cell lines, these appear polyclonal by Southern blot although they are monoclonal by immunoglobulin gene rearrangement; in these lines the mode of replication of the virus by the rolling circle model gives rise to additional longer fragments which have been shown to disappear following acyclovir inhibition of viral replication (26). Therefore, in the absence of viral replication within a tumour, as judged by the absence of short Bam H1-N and Bam H1-J bands, the presence of one longer Bam H1-NJ band confirms the monoclonality of the tumour. The significance of clonality in this type of tumour is presently unclear (12).

Another point to be highlighted is the capacity of this hybridization technique to reveal whether Epstein-Barr virus is replicating in tumour cells. Because acyclovir acts only on the replicative form $(19,23)$, the degree of replication is believed to correlate with the expectation of a clinical response to acyclovir treatment (24). The genome of replicating Epstein-Barr virus is linear, implying that the Bam $\mathrm{Hl}-\mathrm{N}$ and $-\mathrm{J}$ fragments are separated from each other. Thus, the molecular hybridization results should reveal two or more fragments of low molecular weight (Figure 4). Molecular hybridization of the three laboratory cell lines indicated that P3HR-1 and B95-8, but not Raji, harboured replicative linear forms of Epstein-Barr virus. The tumour biopsies from the present two patients were like Raji in that they only contained latent episomal copies of the Epstein-Barr virus genome. However, a percentage of these tumours has been shown to contain replicative copies of the Epstein-Barr virus genome (27), theoretically justifying the use of acyclovir in such cases to prevent infection of additional cells.

Other Epstein-Barr virus restriction fragments may also be used as probes for the presence of the Epstein-Barr virus genome in lymphoma tissue. The Epstein-Barr virus Bam H1-W segment (termed Bam H1-V in some publications) is perhaps the best choice where sensitivity is concerned, because it is repeated several times within the IR1 region of the genome (28); however, it gives no information concerning the state of the Epstein-Barr virus genome (linear or episomal) or the clonality of the tumour.

In cases in which it is only necessary to determine the presence (or absence) of Epstein-Barr virus DNA in tissue specimens, dot blot hybridization is a fast and simple alternative (12). Whole cells or DNA extracted from these cells may be spotted directly onto nitrocellulose filters, which are then hybridized with the probe of choice.

Recently, at the National Centre for EpsteinBarr Virus at the Sainte-Justine Hospital Pediatric Research Centre, the polymerase chain 
reaction method of DNA amplification allowed detection of the Epstein-Barr virus genome within $24 \mathrm{~h}$ by ethidium bromide staining of an amplified 110 basepair viral DNA segment in the same number of tumours that were found to be viral DNA positive by conventional hybridization (12). These results were subsequently confirmed within three days using a phosphorus-32-labelled oligoprobe spanning the amplified segment located within the Bam Hl-W fragment. An additional tumour sample which was doubtful by the conventional method was definitely positive by the labelled oligoprobe confirmatory test. All other tumour samples which were negative by the conventional method also gave negative results by polymerase chain reaction (29).

The mechanism of $\mathrm{B}$ cell transformation induced by Epstein-Barr virus has yet to be determined. However, it is presently believed that three Epstein-Barr virus proteins are involved in this process. Two are nuclear proteins, namely Epstein-Barr nuclear antigens 1 and 2 (30-33), and the other, referred to as latent membrane protein $1(34,35)$, is associated with the cytoplasm and plasma membrane. The authors have previously reported the presence of Epstein-Barr nuclear antigen in Epstein-Barr virus-associated polymorphic B cell lymphoma (12), and emphasize the diagnostic value of the sensitive Epstein-Barr nuclear antigen anticomplement immunofluorescence technique for detecting the presence of Epstein-Barr virus antigens in the tumour cells. Other laboratories have used immunofluorescence with monoclonal antibodies to Epstein-Barr nuclear antigen 2 and latent membrane protein 1 to demonstrate expression of these antigens in tumour tissue (36). Because immunofluorescence can be rather subjective and, therefore, under-

ACKNOWLEDGEMENTS: We thank Mrs Thuy Vu for excellent technical assistance and Dr Gerald Ahronheim for suggestions on the manuscript. P Beauparlant has a studentship from the Conseil des Clubs de Services de Montréal (Téléthon Foundation). C Alfieri is supported by a grant from the JA de Sève (Téléthon) Foundation. JH Joncas is a recipient of a grant from the Cancer Research Society of Montreal and is the Head of the National Centre for Epstein-Barr Virus supported by the Laboratory Centre for Disease Control in Ottawa. Ontario. Bam H1-NJ was kindly provided by Dr Elliott Kieff.

\section{REFERENCES}

1. Henle W, Henle G. Epstein-Barr virus and infectious mononucleosis. N Engl J Med 1973:288:263-4.

2. Henle W, Henle G. Epstein-Barr virus and human malignancies. Adv Viral Oncol 1985;5:201-38. standably dependent on the experience of the observer, molecular hybridization is useful to confirm the diagnosis. This technique also allows detection of the Epstein-Barr virus genome in tumour tissue since the use of the restriction fragment Bam $\mathrm{H} 1-\mathrm{NJ}$ as a probe indicates tumour clonality. In addition, the presence of linear copies of the genome, which are associated with EpsteinBarr virus replication, may warrant the use of acyclovir to limit further replication of the virus and recurrent lymphoproliferation (24).

Polymorphic B cell lymphomas have been reported to occur in 1 to $3 \%$ of organ transplant patients $(11,25,37)$. Since the majority of these lymphomas are associated with primary EpsteinBarr virus infection or reactivation, the authors have monitored Epstein-Barr virus infection in transplant patients at their institution. Primary Epstein-Barr virus infection in young children was frequent, reaching an incidence of over 50\% (in a total of 29 cases) during the first six to 12 months following transplantation (unpublished data). These patients were followed between 1984 and 1990 with serial serological tests for EpsteinBarr virus IgG and IgM antibodies to viral capsid antigens and IgG antibodies to early antigens, in addition to virus isolation from saliva. The diagnosis of primary Epstein-Barr virus infection was confirmed by the appearance of Epstein-Barr viral capsid antigen IgM antibody and stable seroconversion after the disappearance of passively transferred antibodies from blood and/or other biological products. None of the children has yet developed lymphoma. These results may be explained by the small population sample, the length of follow-up, and the fact that immunosuppressive protocols were relatively mild compared to those used in other centres.

3. Purtilo DT, Sakamoto K, Barnabei V, et al. Epstein-Barr virus-induced diseases in males with the X-linked lymphoproliferative syndrome (XLP). Am J Med 1982;73:49-56.

4. Hanto DW, Frizzera G, Gajl-Peczalska KJ, et al. Epstein-Barr virus-induced B-cell lymphoma after renal transplantation. $\mathrm{N}$ Engl J Med 1982;306:913-8.

5. Dummer JS, Bound LM, Singh G, Atchison RW, Kapadia SB, Ho M. Epstein-Barr virus-induced lymphoma in a cardiac transplant recipient. Am J Med 1984;77:179-84.

6. Reece ER, Gartner JG, Seemayer TA, Joncas JH, Pagano JS. Epstein-Barr virus in a malignant lymphoproliferative disorder of B-cells occurring after thymic epithelial transplantation for combined immunodeficiency. Cancer Res 1981;41:4243-7.

7. Shearer WT, Ritz J, Finegold MJ, et al. Epstein-Barr virus-associated B-cell proliferations of diverse clonal origins after bone marrow 
transplantation in a 12 -year old patient with severe combined immunodeficiency. N Engl J Med 1985;312:1151-9.

8. Hardy C, Feusner J, Harada S, et al. Fatal Epstein-Barr virus-induced lymphoproliferation complicating acute lymphoblastic leukemia. J Pediatr 1984;105:64-7.

9. Andiman WA, Eastman R, Martin K, et al. Opportunistic lymphoproliferations associated with Epstein-Barr viral DNA in infants and children with AIDS. Lancet 1985:ii:1390-3.

10. Knowles DM. Inghirami G. Ubriaco A, Dalla-Favera R. Molecular genetic analysis of three AIDSassociated neoplasms of uncertain lineage demonstrates their B-cell derivation and possible pathogenetic role of the Epstein-Barr virus. Blood 1989; 73:792-9.

11. Douglas W, Hanto MD, Kazimiera J. Epstein-Barr virus (EBV) induced polyclonal and monoclonal B-cell lymphoproliferative diseases occurring after renal transplantation. Ann Surg 1983; 198:356-68.

12. Joncas JH, Russo P, Brochu P, et al. Epstein-Barr virus polymorphic B-cell lymphoma associated with leukemia and with congenital immunodeficiencies. J Clin Oncol 1990;8:378-84.

13. Reedman BM, Klein G. Cellular localization of an Epstein-Barr virus (EBV) associated complement-fixing antigen in producer and non-producer lymphoblastoid cell lines. Int J Cancer 1973:11:499-520.

14. Raab-Traub N, Flynn K. The structure of the termini of the Epstein-Barr virus as a marker of clonal cellular proliferation. Cell 1986;47:883-9.

15. Feinberg AP, Vogelstein B. A technique for radiolabeling DNA restriction endonuclease fragments to high specific activity. Anal Biochem 1983; 132:6-13.

16. Alfieri C. Joncas JH. Biomolecular analysis of a defective nontransforming Epstein-Barr virus (EBV) from a patient with chronic active EBV infection. J Virol 1987;61:3306-9.

17. Southern EM. Detection of specific sequences among DNA fragments separated by gel electrophoresis. J Mol Biol 1975;98:503-17.

18. zur Hausen H, Schulte-Holthausen H. Presence of $\mathrm{EB}$ virus nucleic acid homology in a virus free line of Burkitt tumour cells. Nature 1970;227:245-8.

19. Colby BM, Shaw JE, Elion GB, Pagano JS. Effect of acyclovir [9-(2-hydroxyethoxymethyl) guanine] on Epstein-Barr virus DNA replication. J Virol 1980:34:560-8.

20. Hayward SD. Kieff E. DNA of Epstein-Barr virus. II. Comparison of the molecular weights of restriction endonuclease fragments of the DNA of Epstein-Barr virus strains and identification of end fragments of the B95-8 strain. J Virol 1977:23:421-9.

21. Dambaugh T, Beisel C, Hummel M, et al. Epstein-Barr virus (B95-8) DNA. VII. Molecular cloning and detailed mapping. Proc Natl Acad Sci USA 1980;77:2999-3003.

22. Siegel PJ, Clough W, Strominger JL. Sedimentation characterization of newly synthesized Epstein-Barr viral DNA in superinfected cells. J Virol 1981;38:880-5.

23. Datta AK, Colby BM, Shaw JE, Pagano JS.
Acyclovir inhibition of Epstein-Barr virus replication. Proc Natl Acad Sci USA 1980;77:5163-6.

24. Sullivan JL, Medveczky P, Forman SJ. Epstein-Barr virus induced lymphoproliferation: Implication for antiviral chemotherapy. N Engl J Med 1984;311:1163-7.

25. Starzl TE, Porter KA. Iwatsuki S. Reversibility of lymphomas and lymphoproliferative lesions developing under cyclosporin-steroid therapy. Lancet 1984:1:583-7.

26. Sato H. Takimoto T. Tanaka S. et al. Concatameric replication of Epstein-Barr virus: Structure of the termini in virus-producer and newly transformed cell lines. J Virol 1990;64:5295-300.

27. Katz BZ. Raab-Traub N, Miller G. Latent and replicating forms of Epstein-Barr virus DNA in lymphomas and lymphoproliferative diseases. J Infect Dis 1989:160:589-98.

28. Given D, Kieff E. DNA of Epstein-Barr virus. VI. Mapping of the internal tandem reiteration. J Virol 1979;31:315-24

29. Joncas J-H, Alsieri C, Weber MA, Parazis K, Clermont MJ, Chartrand C. Epstein-Barr virus ' $\mathrm{EBV}$ ' inspection in organ transplant pediatric patients. 7th Annual Clinical Virology Symposium, Pan American Group for Rapid Viral Diagnosis Annual Meeting. Florida, 1991

30. Yates J, Warren N, Reisman D, Sugden B. A cis-acting element from the Epstein-Barr viral genome that permits stable replication of recombinant plasmids in latently infected cells. Proc Natl Acad Sci USA 1984:81:3806-10.

31. Rawlins DR, Milman G, Hayward SD, Hayward GS. Sequence-specific DNA binding of the Epstein-Barr virus nuclear antigen (Epstein-Barr nuclear antigen-1) to clustered sites in the plasmid maintenance region. Cell 1985;42:859-68.

32. Thorley-Lawson DA. Basic virological aspects of Epstein-Barr virus infection. Semin Hematol 1988:25:247-60.

33. Wang F, Gregory C, Sample C, et al. Epstein-Barr virus latent membrane protein (LMP-1) and nuclear proteins 2 and $3 \mathrm{C}$ are effectors of phenotypic changes in B lymphocytes: EBNA-2 and LMP-1 cooperatively induce CD23. J Virol 1990;64:2309-18.

34. Kieff E, Liebowitz D. Epstein-Barr virus and its replication. In: Fields BN, Knipe DM, Chanock RM, et al, eds. Virology, 2nd edn. New York: Raven Press, 1990:1889-920

35. Abbot SD, Rowe M, Cadwallader K, et al. Epstein-Barr virus nuclear antigen 2 induces expression of the virus-encoded latent membrane protein. J Virol 1990;64:2126-34.

36. Young L, Alfieri C, Kennessy K, et al. Expression of Epstein-Barr virus transformation-associated genes in tissues of patients with EBV lymphoproliferative disease. N Engl J Med 1989;321:1080-5.

37. Nalesnik MA, Locker J. EBV-associated lymphoproliferative disorders in a large transplant population. In: Ablashi DV, Faggioni A, Krueger GRF, Pagano JS, Pearson GR, eds. Epstein-Barr Virus and Human Disease. Clifton, New Jersey: Humana Press, 1989:271-5. 


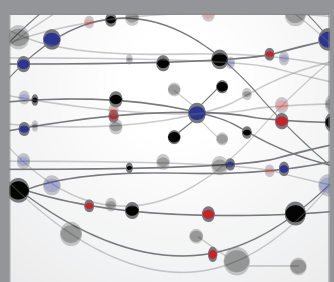

The Scientific World Journal
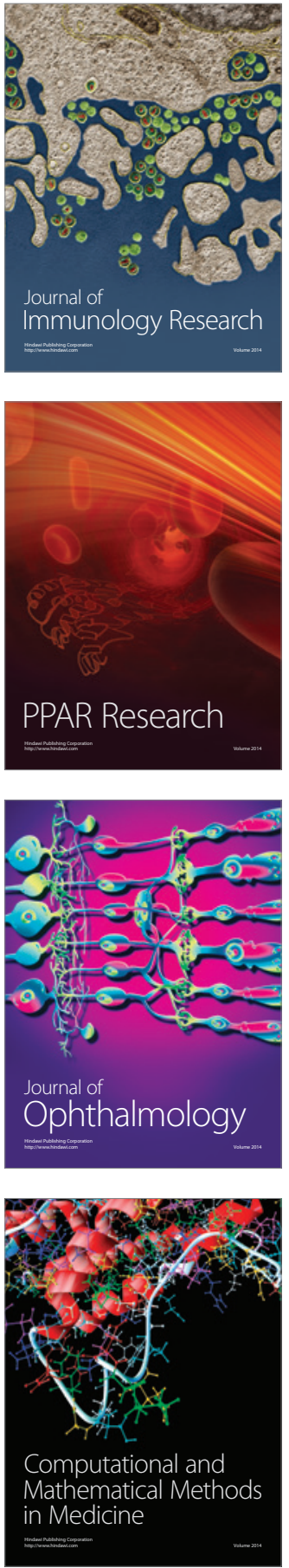

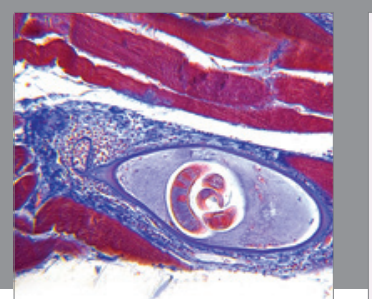

Gastroenterology Research and Practice

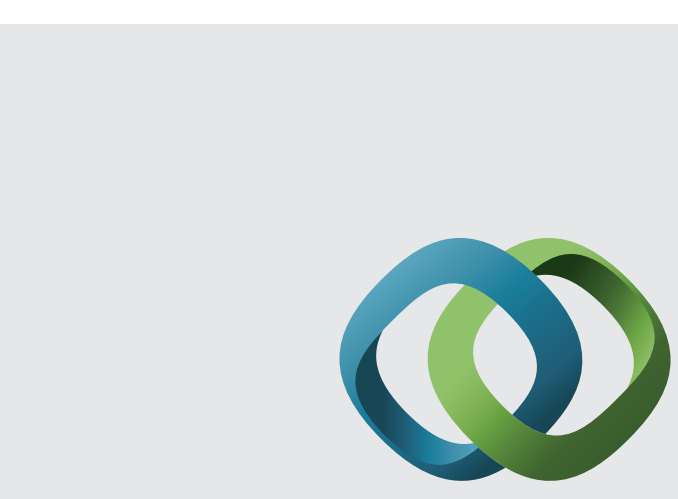

\section{Hindawi}

Submit your manuscripts at

http://www.hindawi.com
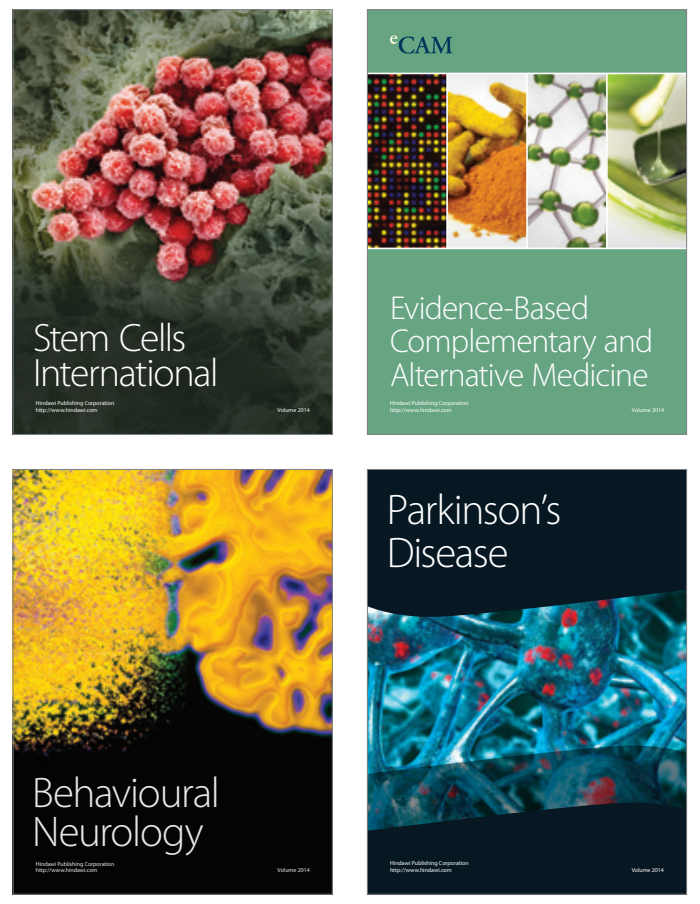
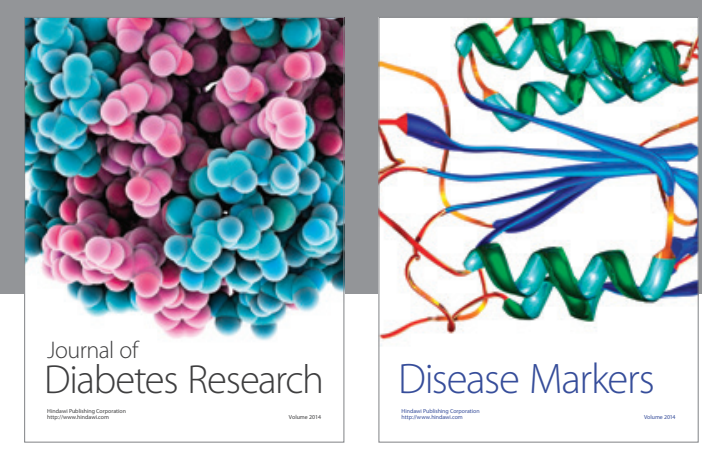

Disease Markers
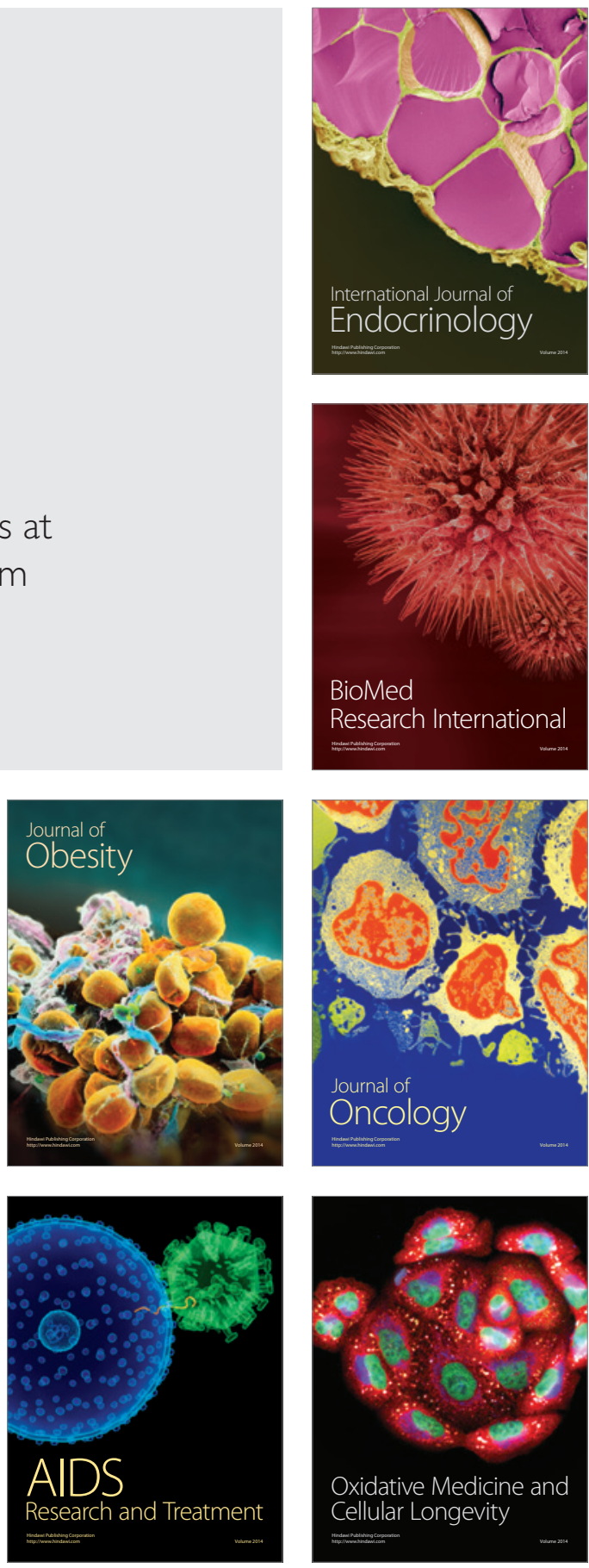